\title{
"What is a scientific ideology?" Extracts from Ideology and rationality in the history of the life sciences by G. Canguilhem
}

\author{
Camille Akmut
}

February 8, 2020

summary a modest philosopher-historian of the sciences re-examines his own work and the notion of "[scientific] ideology"; the latter's history - from 18th c. French philosophy through Marx to Foucault - he retraces for us here. 


\section{FOREWORD}

To make mistakes is human, to persevere in error is evil.

It is not up to me to say how aberrant the following texts are - reunited here in a single edition.

I am too old [for this] now (...)

Beginning in 1967-68, I started including the concept of "scientific ideology" in my teaching, and some articles and presentations - influenced by Michel Foucault and Louis Althusser;

This was not merely to signal my interest in and approval of novel and original contributions to the history of sciences, but a means to recall the lessons of an old master - updated, not rejected; whose books I had read, having not attended his classes :

The lessons of Gaston Bachelard my young colleagues - whatever liberties they may have taken in the process - too have learned.

(...)

I'd like to answer one question, however, be it only for myself. The author of Archeologie du savoir [Michel Foucault], whose analyses have sure been most useful to me, distinguishes four major steps in the history of knowledge:

positivism, epistemologization, scientificity, and formalization (pp. 243-247).

I'm not sure if was able to identify these various moments in the studies that I publish and the sciences whose history I have written and outlined here, in the way that Mr. Foucault would like.

It appears to me that none of them have been able to reach beyond the formalization step ${ }^{1}$; disregarding the pretensions of some geneticists.

But, I do believe, contrary to Mr. Foucault, that not all sciences are made equal when it comes to their contributions to modern science : take the experimental medicine of Claude Bernard and the microbiology of Pasteur, for example.

I will gladly accept the critique of not having sufficiently shed light on [these] various scientific changes.

But the history of medicine and biology, in the XIXth c., does not lend itself to such analysis as well as chemistry during that same period would; the epistemological dissection of the conditions of their "progress", I mean.

Could one not defend the thesis that Claude Bernard's physiological medicine gives us an example of a science whose epistemologization, at the hands of its own author, himself fond of philosophizing, is more "advanced" than its positivism?

While Pasteur, chemist, not doctor, was more preoccupied with the positivism of his research, than bothered by the coherence of their epistemology?

It may well be that I was wrong, and my analyses not detailed or rigorous enough. But, this task I leave to others : prudence, laziness, or incapacity?

Georges Canguilhem June 1977

\footnotetext{
${ }^{1}$ See the works of J.H. Woodger : Axiomatic Method in Biology, Cambridge, 1937 ; Fomalization in Biology ... 1958 [in English in the original]
} 
1. - What is a scientific ideology?

\section{$(\ldots)$}

Today's popularity of the notion of ideology has origins that leave little doubts. The vulgarisation of Karl Marx's thought (...)

Borrowed from XVIIIth c. French philosophy, this term has now the meaning we know it to have : But, then, ideology was - in the works of Cabanis and Destutt de Tracy - the science of ideas' genesis. (...)

In The German Ideology Marx had opposed to various ideologies, political, legal, economic, religious, etc., the economic science - which is to say the science he wished to found. (...)

Marx committed himself to showing how - faced with the marxist science of economy - all economic-political ideologies implied a class situation which made it impossible for bourgeois intellectuals to recognize in a mirror, a mirror : not bare, naked science of things as they are, but a reversal of the relationships between Men and Men, and Man and nature. None of them [as a consequence] came close to truth.

\section{$(\ldots)$}

But, isn't it remarkable that, in The German Ideology Marx had recognized all ideologies as ideologies, but not science as one of them?

(...)

In Contributions to a critique of political economy, Marx had met a "difficulty" in the fact that art - in its relationships with social productions - could nonetheless retain beyond its historical conditions, and beyond their vanishing, a certain permanent value.

But, what Marx bestowed to Greek art, should marxism now refuse to Greek geometry? 


\section{References}

Canguilhem, Georges. 2000. Ideologie et rationalite dans l'histoire des sciences de la vie. 2nd, revised ed..

(various passages were translated) 